\title{
ELABORATION AND CHARACTERIZATION OF GLUTEN-FREE PIZZA AND COOKIE DOUGHS WITH BANANA WASTE FLOUR: ALTERNATIVES TO CELIACS
}

\author{
Isabella Fernanda Camargo Queiroz ${ }^{1}$, Kate Mariane Adesunloye ${ }^{1}$, Isabela Rezende Ferreira ${ }^{2}$, \\ Luane Aparecida do Amaral $^{3}$, Fernanda Caspers Zimmer ${ }^{4}$ Priscila Neder Morato ${ }^{1}$, Mariana \\ Manfroi Fuzinatto ${ }^{1 凶}$ \\ ${ }^{1}$ Food Engineering, State University of Mato Grosso do Sul (UEMS), Brazil \\ ${ }^{2}$ Graduate Program of Food Science and Technology, Federal University of Grande Dourados (UFGD), Brazil \\ ${ }^{3}$ Faculty of Pharmaceutical Sciences, Food and Nutrition (FACFAN), Federal University of Mato Grosso do \\ Sul (UFMS), Brazil \\ ${ }^{4}$ Graduate Program of Chemistry, State University of Maringá (UEM), Brazil \\ mariana.fuzinatto@gmail.com
}

https://doi.org/10.34302/crpjfst/2021.13.1.2

\begin{tabular}{ll}
\hline Article history: & ABSTRACT \\
Received: & The present study aims to evaluate the nutritional composition and \\
28 April 2020 & acceptability of gluten-free pizza and cookie dough produced with banana \\
Accepted: & (Musa ssp.) waste (bract)to improve their nutritional quality and reduce \\
15 February 2021 & banana farming waste production. Bract flour was analysed for centesimal \\
composition, water activity, minerals (Fe, Na and K) and color. For pizza & dough elaboration, rice, sweet tapioca and bract flours were used. For \\
Keywords: & cookieselaboration, cassava starch and bract flours were used to replace \\
Gluten-free products; & wheat flour. The centesimal composition and the phenolic compounds \\
Agro-industrial waste; & content were determined, and the sensory analyses were performed for \\
Banana bract; & both formulations. The results showed that bract flour presentsa high \\
Acceptability. & dietary fiber and minerals content and a lowcaloric value. Sensory analysis \\
& revealed the formulations acceptance and an even better evaluation for the \\
& cookies. The results suggested that banana bract flour may be included in \\
gluten-free bakery products to improve their nutritional quality.
\end{tabular}

\section{Introduction}

Wheat products manufacture occurs predominantly due to thegluten proteins technological characteristics, whose hydration provides viscoelastic properties to the batter that incorporate gases during fermentation (Sciarini et al. 2010). On the other hand, some individuals are gluten intolerant (Fritz \& Chen, 2017). In this context, the unique treatment for celiac disease (CD), a chronic immunemediated enteropathy triggered by genetically predisposed individuals' exposure to dietary gluten, is agluten-free (GF) diet (Farage et al. 2018; Verma et al. 2017).
As the diet for celiacs is considered repetitive and restrictive, the food industry has invested in improving the gluten-free foods production to please consumers making the new products sensorially similar to those containing gluten. International studies show that $1 \%$ of the world population is celiac andaccording to the Brazilian Federation of Celiac Associations (Fenacelbra), around 2 million people in Brazil are affected by the disease (PRATESI and GANDOLFI, 2005). According to Farias (2009), the foods with the highest demand for transformation by the industry to be included in the celiac diet are bread, chocolate, pasta in general (spaghetti 
and gnocchi), pizza and sausages (sausageand mortadella). Despite this, there is a lack of raw materials for their preparation.

When compared to conventional products, GF products generally present higher fat and sugar content, as well as lower protein and dietary fiber amounts (El Khoury et al. 2018; Fry et al. 2018). Due to their lower structural quality, these products are often less attractive in terms of appearance, taste, aroma and texture (El Khoury et al. 2018). Techniques, such as the use of dietary fibersare applied to improve their properties, affecting the dough and starch cohesion properties (Aprodu \& Banu, 2015; Gao et al. 2018).

There is a trend among consumers for healthier foods and a demand for sustainable production by the agro-industrial waste recovery and reuse (Vialta et al. 2010). Some studies have revealed the relevant nutrition potential fromsuch waste including vitamins, minerals, fiber and bioactive compounds (Gawlik-Dziki, 2012).

According to Shah et al. (2005), banana cultivation (Musa spp.) generates approximately 220 tons of waste per hectare. The banana inflorescence is formed by male flowers with their respective bracts (Sheng et al. 2010). Since it has no market value in Brazil, it is discarded as banana waste (Sheng et al. 2011). The bract is dietary-fiber-rich and presentskey antioxidant properties due to the presence of bioactive compounds (Padam et al. 2012). According to Basumatary \& Nath (2018), banana bract presents an excellent phenolic compound content playing a significant role in free radical inhibition processes (Fawole et al. 2012).

Thus, the gluten-free pizza and cookie doughs formulating addedwith banana bract flour may facilitate the consumption of a potentially functional ingredient; adding value to this waste, in addition to improving the nutritional quality of the products without significantly affecting the sensory attributes, hence the need to evaluate this effect and the acceptance level.

\section{Materials and methods \\ 2.1.Banana bract flour, pizza and cookie doughs elaboration}

Banana (Musa spp.) bracts were obtained from the Federal University of Grande Dourados (UFGD - Campus II) organic vegetable garden, Dourados -MS, Brazil. Harvesting took place in the mornings, between August 2017 and March 2018.

The preparations were done at the UEMS Food Laboratory - Naviraí Campus. The flour was elaborated according to methodology described by Borges \& Mendonça (2019). The bracts were removed from the inflorescence, washed in tap water, and then cut into standardized sizes with an approximate $1 \mathrm{~cm}$ thickness. Afterward, they were weighed and immersed in a $200 \mathrm{mg} . \mathrm{L}^{-1}$ sodium hypochlorite solution for 15 minutes. After that, they were bleached and immersed in a $0.5 \%$ citric acid solution for 1 minute, placed in aluminum containers $(30 \mathrm{~cm} \times 40 \mathrm{~cm})$ and oven-dried at $65{ }^{\circ} \mathrm{C}$ for 18 hours. The milling was performed in a blade mill, obtaining 60-mesh size flour. The flour was stored in dark glass bottlespreviously sanitized and stored at $4{ }^{\circ} \mathrm{C}$, until its use.

The other essential ingredients were purchased from local markets in the municipality of Naviraí-MS. The ingredients and their concentrations were defined by preliminary sensory tests, maintaining the formulations main characteristics, as per Tables 1 and 2.

For the pizza dough preparation, baker's yeast was hydrated with sugar and warm water $(50 \mathrm{ml})$. The other dry ingredients were added and homogenized with eggs and the remaining water. Olive oil and a pre-prepared mixture were added tothe other ingredients until asmooth-structured homogeneous dough was obtained. The doughs were cut into equal parts, placed on $23 \mathrm{~cm}$ diameter aluminum forms and baked in a gas oven for 20 minutes at $180^{\circ} \mathrm{C}$.

For the cookies preparation, pre-tests were carried out to determine the banana bract flour and cassava starch concentrations. The methodology by Silvia et al. (1998) was used, 
with adaptations. The dry ingredients were homogenized with eggs and butter until smoothing. The dough was divided into portions, laminated at $5 \mathrm{~mm}$ thickness and cut into a $30 \mathrm{~mm}$ diameter. Uniform circumference discs were weighed before baking in an automatic electric oven for 15 minutes at 200 ${ }^{\circ} \mathrm{C}$.

Table 1. Pizza formulations with variation of banana bract flour and mixed gluten free flour.

\begin{tabular}{|c|c|c|c|}
\hline Ingredients & Pizza P1 & Pizza P2 & Pizza P3 \\
\hline Sugar (g) & 5.00 & 5.00 & 5.00 \\
\hline Water (m) & 142.00 & 142.00 & 142.00 \\
\hline Extra Virgin Olive Oil (ml) & 15.00 & 15.00 & 15.00 \\
\hline Banana Bract Flour (g) & 30.00 & 30.00 & 50.00 \\
\hline Mixed GF Flour (g) & 450.00 & 246.00 & 450.00 \\
\hline Biological yeast (g) & 10.00 & 10.00 & 10.00 \\
\hline Eggs (g) & 30.00 & 30.00 & 30.00 \\
\hline Salt (g) & 3.50 & 3.50 & 3.50 \\
\hline
\end{tabular}

Mixed GF flour composed of rice flour (50\%) and sweet tapioca flour (50\%).

Table 2. Cookie formulations with variation of banana bract flour and cassava starch.

\begin{tabular}{|c|c|c|c|}
\hline Ingredients & Cookie C1 & Cookie C2 & Cookie C3 \\
\hline Brown Sugar(g) & 75.00 & 75.00 & 75.00 \\
\hline Refined Sugar (g) & 100.00 & 100.00 & 100.00 \\
\hline Baking Soda(g) & 5.00 & 5.00 & 5.00 \\
\hline Cocoa Powder 50\% (g) & 10.00 & 10.00 & 10.00 \\
\hline Banana Bract Flour (g) & 10.00 & 10.00 & 15.00 \\
\hline Cassava Starch Flour (g) & 250.00 & 200.00 & 225.00 \\
\hline Butter w/ salt (g) & 75.00 & 75.00 & 75.00 \\
\hline Eggs(g) & 15.00 & 15.00 & 15.00 \\
\hline
\end{tabular}

\subsection{Banana bract flour characterization}

Banana bract flour centesimal composition analysis was performed in triplicate, as follows: moisture by the desiccation mass loss gravimetric method in an oven at $105^{\circ} \mathrm{C}$; ash by incineration method in muffle at $550{ }^{\circ} \mathrm{C}$ (AOAC, 2005); crude protein by MicroKjeldahl method (AOAC, 2011), using 5.75 as a nitrogen conversion factor into plant proteins (Brazil, 2001) and lipids by Bligh \& Dyer (1959) method. Total dietary fiber and soluble and insoluble fractions were performed by theenzymatic method (AOAC, 2000), and water activity performed by hygrometer (Labuza, 1975).

Carbohydrates were determined by the difference of the values found for moisture, ash, protein, lipid and total dietary fiber in $100 \mathrm{~g}$ of product (AOAC, 1995). The total caloric value was calculated using lipids $(9.03 \mathrm{kcal} / \mathrm{g})$, protein $(4.27 \mathrm{kcal} / \mathrm{g})$ and carbohydrates $(3.82 \mathrm{kcal} / \mathrm{g})$ as parameters (Merrill \& Watt, 1973).

Samples were digested in a microwave oven using nitric acid, and the macro minerals $(\mathrm{Fe}, \mathrm{Na}, \mathrm{K})$ were determined by atomic absorption spectrophotometry and the results expressed as mg $100 \mathrm{~g}^{-1}$ sample and standard deviation (Aquino et al. (2014, Xu et al. 1988). Color analysis was evaluated by the CIELAB system in terms of $\mathrm{L}, \mathrm{a}^{*}$ and $\mathrm{b}^{*}$ colorimetric coordinates (Gonnet, 1998). The average results were expressed as percentage \pm standard deviation. 


\subsection{Pizza and cookie doughs characterization}

Centesimal composition analyses were performed on the three formulations of both products using the methods previously described for moisture, ash, lipids, proteins and carbohydrates. Total phenolic compounds determination was performed by FollinCiocauteau method with modifications proposed by Asami et al. (2003), in triplicate. Extracts were prepared with a $70 \%$ ethanol (v/v) extraction solution. $200 \mu \mathrm{l}$ aliquots of extract, $60 \mu \mathrm{l}$ Follin-Ciocauteau reagent and 2 $\mathrm{mL}$ sodium carbonate solution $(7 \% \mathrm{w} / \mathrm{v})$ were taken. The readings were taken at a $720 \mathrm{~nm}$ wavelength. The results were expressed as mg gallic acid equivalent (GAE) / g dry matter.

\subsection{Pizza and cookiedoughssensory analysis}

The sensory analysis was performed with the UEMS Human Ethics Committee approval under opinion \# 1,858,034/2016. The formulation tests were performed at the UEMS Food Laboratory / Naviraí Campus, with 100 randomly chosenuntrained (19-59 years old) (male and female) adult tasters.

The samples were presented in coded disposable plastic plates on trays with a glass of water and a napkin. The pizzas were prepared with industrialized tomato sauce, mozzarella cheese and oregano. For the evaluation, the structured nine-point hedonic scale was used (Dutcoski, 2013).

\subsection{Statistical Analysis}

The results were expressed as average \pm standard deviation (SD) and the triplicate measurements of pizza and cookie doughs were submitted separately to the analysis of variance (ANOVA) and Tukey test at a 5\% significance level $(\mathrm{p} \leq 0.05)$ using the STATISTICA 7.0 software (Statsoft, 2004).

\section{Resultsanddiscussions}

\subsection{Banana bract flour characterization}

The physicochemical and color analysis results are shown in Table 3 . The result for moisture content is in accordance with the
Brazilian Law (Brazil, 2005), which establishes a $15 \mathrm{~g}-100 \mathrm{~g}$ maximumlimit forproduct. The water activity results $(0.454 \pm 0.04)$ ensure greater product stability (Cecchi, 2003).

The ash content was higher than that obtained for green banana flour $(2.27 \%)$ (Medeiros et al., 2010). Both ash and protein contents $(9.98 \pm 0.13 \%)$ were lower than those for dehydrated banana inflorescence (14.4 \pm $0.64 \%$ and $14.5 \pm 0.40 \%$, respectively). On the other hand, lipids contentwas higher $(6.27 \pm$ $0.24 \%$ ) when compared with the same study (4.04 $\pm 0.07 \%)$ (Fingolo et al., 2012).

The results for total dietary fiber $(56.14 \pm$ $2.41 \%)$ and insoluble fiber $(50.32 \pm 1.35 \%)$ were higher than those found by Scorsatto et al. (2017) in eggplant flour, $39.2 \%$ and $28.83 \%$ respectively. Bhaskar et al. (2012) obtained highertotal fiber, soluble and insoluble fraction results $(65.6 \pm 1.3 ; 7.3 \pm 0.2 \%$ and $58.3 \pm$ $1.0 \%$, respectively) for dehydrated banana inflorescence.

Banana bract flour is classified as high fiber content (Brazil, 2012)and to achieve this classification it must contain $6 \mathrm{~g}$ of fiber per $100 \mathrm{~g}$. Therefore, it is a potential product to achieve the dietary recommendation since the fiber intake by the population is below the recommended one (Grooms et al. 2013). Both the amount of carbohydrates and the caloric valuewere lowerthan those forwatermelon rind flour $(65.95 \pm 0.04 \%$ and $317.88 \pm 0.04 \mathrm{Kcal}$, respectively) (Cristo et al. al., 2018).

Borges et al. (2009), analyzed green banana flouras having higher potassium content $(1,180$ mg $100 \mathrm{~g}-1)$ and lower iron content $(17.80$ mg $100 \mathrm{~g}-1$ ) than the bract flour. For color,the $\mathrm{L}^{*}$ value shows the luminosity and the higher this value, the lighter the sample thus, the flour tended to darken. Fora*, a positive value was obtained, which indicates an even greater darkening. According to Takatsui (2011), when $a^{*}$ and $b^{*}$ coordinates approach zero, the colors are neutral. 
Table 3. Characterization and color analysis of banana bract flour

\begin{tabular}{|c|c|}
\hline Composition & \% $\pm \mathbf{D P}$ \\
\hline Moisture & $3.86 \pm 0.11$ \\
\hline Water Activity (Aw) & $0.454 \pm 0.04$ \\
\hline Ash & $10.46 \pm 0.02$ \\
\hline Proteins & $9.98 \pm 0.13$ \\
\hline Lipids & $6.27 \pm 0.24$ \\
\hline Total Fiber & $56.14 \pm 2.41$ \\
\hline Soluble fiber & $5.82 \pm 2.28$ \\
\hline Insoluble fiber & $50.32 \pm 1.35$ \\
\hline Carbohydrates & $12.42 \pm 0.53$ \\
\hline VC (kcal/100g) & $150.40 \pm 10.63$ \\
\hline Fe & $65.22 \pm 0.95$ \\
\hline Na & $294.46 \pm 3.97$ \\
\hline K & $322.04 \pm 2.53$ \\
\hline $\mathbf{L}^{*}$ & $33.66 \pm 0.11$ \\
\hline $\mathbf{a}^{*}$ & $4.28 \pm 0.06$ \\
\hline $\mathbf{b}^{*}$ & $1.98 \pm 0.11$ \\
\hline
\end{tabular}

Data were presented as mean \pm standard deviation (SD). VC: Caloric value.

The theoretical calculation was performed for carbohydrates and caloric value $(\mathrm{Kcal} / 100 \mathrm{~g})$.

\subsection{Pizza and cookie doughs characterization}

According to the Brazilian Institute of Geography and Statistics (IBGE, 2011), wheatbased pizza dough formulations contain an approximate $39.79 \%$ moisture content. Moisture contents are related to product crispness, an important sensory attribute that, is reduced at high moisture levels (Guimarães \& Silva, 2009). When evaluating the results for doughs, all formulations were below this content level.

For the cookie formulations, a significant statistical difference in moisture content between $\mathrm{C} 3$ and the other formulations could be observed due to the higher bract flourcontent. According to the Brazilian Health Regulatory Agency (ANVISA), the maximum moisture content for cookies must be $15 \% \mathrm{w} /$ w (BRAZIL, 2005). Thus, the cookies are in accordance with Brazilian law.

For pizza dough`s ash, protein and lipid content, the highest averages obtained for the P2 formulation were inversely proportional to the mixed flour concentration. One of the reasons was the other ingredients concentration in P2 formulation.
The three pizza dough formulations had a lower protein content compared to wheat-based pizza dough, with an $8.22 \%$ averageprotein content (IBGE, 2011). According to the Brazilian Food Composition Table (TACO, 2011), wheat flour has a $9.8 \mathrm{~g} / 100 \mathrm{~g}$ protein average content and, as already described, banana bract flour has an $9.98 \mathrm{~g} / 100 \mathrm{~g}$ average protein content (Table 4), making the amount of the latter necessary for the dough preparation lower than that of wheat flour. Rice flour and sweet flour were used as replacements for wheat flour, both presenting reduced $8.4 \mathrm{~g} /$ $100 \mathrm{~g}$ and $0.4 \mathrm{~g} / 100 \mathrm{~g}$ protein valueson a dry basis, respectively (TACO, 2011). These values may justify the results found for protein levels on formulations when compared to a wheatbased pizza formulation.

Pizza (P2) formulation obtained a lipid average similar to the findings from Monteiro (2013) on pizzas made with rice, yam and quinoa flours with $4.74 \%$ to $6.17 \%$ averages. However, all samples presented lower lipid contents than those reported by IBGE (2011) for wheat-based pizza $(11.35 \%)$. 
Carbohydrate contents showed a significant statistical difference between the three pizza samples. El-Beltagi et al. (2017) evaluated pizza doughs with partial wheat flour replacement by three different chickpea flour or carp fish powder concentrations, which present higher protein and carbohydrate contents. However, a lower ash contents was observed, mainly due to the high ash contents in banana bract flour.

For cookie formulations, $\mathrm{C} 2$ showed a lower ash value $(1.55 \pm 0.08)$, since it has a lower banana bract flouramount. $\mathrm{C} 1$ and $\mathrm{C} 3$ formulations achieved similar results to the study by Freitas et al. (2014), who evaluated gluten-free cookies added with pumpkin seed flour and baru seed flour obtaining $1.93 \mathrm{~g} / 100 \mathrm{~g}$ and $1.76 \mathrm{~g} / 100 \mathrm{~g}$, respectively.

There was no statistical difference forthe cookies' protein, lipid and carbohydrate contents $(\mathrm{P} \geq 0.05)$. Mariani et al. (2015) prepared gluten-free cookies from rice bran, rice flour and soy flour and obtained higher protein values $(11.16-14.22 \mathrm{~g} / 100 \mathrm{~g})$ and lower lipids $(20.29-22.13 \mathrm{~g} / 100 \mathrm{~g})$ and carbohydrates $(37.27$ - 48.20g / 100g) values. These results may be due to the energetic and non-protein characteristics of the ingredients used in the formulations.
From the results, the pizza dough with the lowest flour content showed the highest phenolic compoundscontent, mainly due to the highest concentration of products used, however, no statistical differences were seen in the pizza samples. For cookies, C3 formulation with the highest banana bract flour content presented the highest phenolic compoundscontent, which was statistically different $(\mathrm{P} \leq 0.05)$ from the other samples, confirming the considerable phenolic compounds contentin banana bract flour.

One of these products benefits was the good nutritional composition, obtaining a higher fiber and phenolic compounds content and a lower carbohydrate content.

Several studies have shown that the consumption of antioxidant substances in a daily dietproduces an effective protective action against the natural oxidative processes in the body, preventing diseases and delaying the body`s aging process. Also, adequate fiber intakeappears to reduce the risk of chronic diseases development such as coronary artery disease, stroke, hypertension, diabetes mellitus and some gastrointestinal disorders, among other health benefits.

Table 4. Characterization of pizza dough and cookie biscuits.

\begin{tabular}{|c|c|c|c|c|c|c|}
\hline Sample & $\begin{array}{c}\text { Moisture } \\
\mathbf{( g / 1 0 0 g )}\end{array}$ & $\begin{array}{c}\text { Ash } \\
\mathbf{( g / 1 0 0 g )}\end{array}$ & $\begin{array}{c}\text { Proteins } \\
\mathbf{( g / 1 0 0 g})\end{array}$ & $\begin{array}{c}\text { Total Lipids } \\
\mathbf{( g / 1 0 0 g )}\end{array}$ & $\begin{array}{c}\text { Carbohydrat } \\
\text { es } \\
\mathbf{( g / 1 0 0 g})\end{array}$ & $\begin{array}{c}\text { Phenolics } \\
\text { Compounds } \\
\mathbf{( m g} \\
\text { EAG/100g }\end{array}$ \\
\hline P1 & $28.63 \pm 0.31^{\mathrm{b}}$ & $2.49 \pm 0.08^{\mathrm{b}}$ & $0.62 \pm 0.01^{\mathrm{b}}$ & $3.73 \pm 0.09^{\mathrm{b}}$ & $64.53 \pm 0.23^{\mathrm{a}}$ & $72.08 \pm 0.20^{\mathrm{a}}$ \\
\hline $\mathbf{P 2}$ & $28.63 \pm 0.31^{\mathrm{b}}$ & $3.80 \pm 0.06^{\mathrm{a}}$ & $0.75 \pm 0.02^{\mathrm{a}}$ & $5.71 \pm 0.12^{\mathrm{a}}$ & $61.24 \pm 0.50^{\mathrm{b}}$ & $98.58 \pm 0.22^{\mathrm{a}}$ \\
\hline P3 & $28.49 \pm 0.31^{\mathrm{a}}$ & $2.33 \pm 0.02^{\mathrm{c}}$ & $0.61 \pm 0.03^{\mathrm{b}}$ & $3.44 \pm 0.01^{\mathrm{c}}$ & $58.51 \pm 1.00^{\mathrm{c}}$ & $87.36 \pm 0.11^{\mathrm{a}}$ \\
\hline $\mathbf{C 1}$ & $7.31 \pm 0.15^{\mathrm{a}}$ & $1.70 \pm 0.05^{\mathrm{a}}$ & $0.43 \pm 0.23^{\mathrm{a}}$ & $34.16 \pm 15.31^{\mathrm{a}}$ & $56.40 \pm 15.48^{\mathrm{a}}$ & $195.21 \pm 0.41^{\mathrm{b}}$ \\
\hline $\mathbf{C 2}$ & $7.64 \pm 1.33^{\mathrm{a}}$ & $1.55 \pm 0.08^{\mathrm{b}}$ & $1.02 \pm 0.60^{\mathrm{a}}$ & $31.90 \pm 8.81^{\mathrm{a}}$ & $57.88 \pm 8.53^{\mathrm{a}}$ & $307.29 \pm 0.65^{\mathrm{b}}$ \\
\hline $\mathbf{C 3}$ & $2.78 \pm 1.51^{\mathrm{b}}$ & $1.80 \pm 0.02^{\mathrm{a}}$ & $0.89 \pm 0.15^{\mathrm{a}}$ & $38.04 \pm 9.80^{\mathrm{a}}$ & $56.50 \pm 8.91^{\mathrm{a}}$ & $471.21 \pm 0.20^{\mathrm{a}}$ \\
\hline
\end{tabular}

Date were present as mean \pm standard deviation (SD). The pizza dough formulations were analyzed separately from the cookie formulations. The averages in the same column. followed by different letters. differ statistically from each other by Tukey test at $5 \%$ probability.

'P1 Pizza Dough: 450g mixed GF flour and 30g bract flour; P2: 250g of mixed GF flour and 30g of bract flour; P3: 450g of mixed GF flour and $50 \mathrm{~g}$ of bract flour.

${ }^{2}$ Cookie C1: 250g of cassava starch flour and 10g of bract flour; C2 200g of cassava starch flour and 10g of bract flour; C3 $225 \mathrm{~g}$ of cassava starch flour and $15 \mathrm{~g}$ of bract flour. 
Table 5. Averages of sensory acceptability and purchase intention of the pizza doughs of the cookie biscuits added banana flour

\begin{tabular}{|c|c|c|c|c|c|c|}
\hline \multicolumn{2}{|c|}{ Sample } & Color & Aroma & Texture & Flavour & $\begin{array}{c}\text { Global } \\
\text { Impression }\end{array}$ \\
\hline \multirow{3}{*}{ 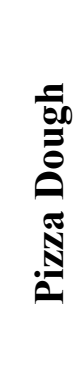 } & P1 & $6.21 \pm 1.85^{\mathrm{a}}$ & $6.88 \pm 1.68^{\mathrm{a}}$ & $6.42 \pm 1.79^{\mathrm{a}}$ & $6.68 \pm 1.69^{\mathrm{a}}$ & $6.56 \pm 1.72^{\mathrm{a}}$ \\
\hline & $\mathrm{P} 2$ & $5.76 \pm 1.72^{\mathrm{a}}$ & $6.47 \pm 1.60^{\mathrm{ab}}$ & $5.99 \pm 1.62^{\mathrm{ab}}$ & $6.46 \pm 1.68^{\mathrm{ab}}$ & $6.25 \pm 1.69^{\mathrm{ab}}$ \\
\hline & P3 & $5.83 \pm 1.71^{\mathrm{a}}$ & $6.00 \pm 1.84^{\mathrm{b}}$ & $5.73 \pm 1.65^{b}$ & $5.96 \pm 1.73^{b}$ & $5.72 \pm 1.66^{\mathrm{b}}$ \\
\hline \multirow{3}{*}{$\begin{array}{l}0 \\
\\
0\end{array}$} & $\mathrm{C} 1$ & $6.88 \pm 1.63^{\mathrm{a}}$ & $7.04 \pm 1.52^{\mathrm{ab}}$ & $6.93 \pm 1.55^{\mathrm{b}}$ & $6.69 \pm 1.69^{b}$ & $6.80 \pm 1.54^{\mathrm{b}}$ \\
\hline & $\mathrm{C} 2$ & $7.09 \pm 1.58^{\mathrm{a}}$ & $6.90 \pm 1.62^{b}$ & $7.06 \pm 1.36^{\mathrm{ab}}$ & $6.84 \pm 1.77^{b}$ & $7.12 \pm 1.57^{\mathrm{ab}}$ \\
\hline & $\mathrm{C} 3$ & $6.98 \pm 1.58^{\mathrm{a}}$ & $7.49 \pm 1.33^{\mathrm{a}}$ & $7.53 \pm 1.34^{\mathrm{a}}$ & $7.78 \pm 1.32^{\mathrm{a}}$ & $7.38 \pm 1.26^{\mathrm{a}}$ \\
\hline
\end{tabular}

Data were presented as mean \pm standard deviation (SD). The pizza dough formulations were analyzed separately from the cookie formulations. The averages in the same column. followed by different letters. Differ statistically from each other by the Tukey test at $5 \%$ probability.

1 P1 Pizza Pasta: 450g mixed flour and 30g bract flour; P2: 250g of mixed flour and 30g of bract flour; P3: 450g of mixed flour and $50 \mathrm{~g}$ of bract flour.

2 Cookie C1: 250g of manioc starch flour and $10 \mathrm{~g}$ of bract flour; C2 $200 \mathrm{~g}$ of manioc starch flour and $10 \mathrm{~g}$ of bract flour; C3 $225 \mathrm{~g}$ of manioc starch flour and $15 \mathrm{~g}$ of bract flour.

\subsection{Pizza and cookiedoughs sensory analysis}

Sensory analysis is a critical factor for new products acceptance or rejection(Sivakumar et al. 2010). Changes in the modified foods sensory characteristics are expected, such as in the dough structure with the gluten removal (Padalino et al. 2016). The sensory analysis results are shown in Table 5.

Taste and texture are the determining factors in choosing pizza dough (Bingham et al. 2011). Gluten-free pizza dough formulations added with banana bract flour received between 5.57 ("neither liked nor disliked") and 6.88 ("slightly liked")on average for all hedonic attributes. Such results were similar to those obtained by Russo et al. (2012), who developed pizza doughs added with whole wheat flour and different flaxseed flour concentrations, with aroma, taste, texture and color attributesclassified as "slightly liked". The exceptions occurred for the "flavor" attribute, where the formulation added with 5\% flaxseed flour was classified as "moderately liked" and for the "texture" attribute, where the formulation added with $7.5 \%$ flaxseed flour was classified as "neither liked nor I disliked it".

No significant statistical difference was observed in the "color" attribute among the pizza dough samples. Pizza dough P3 formulation added with $450 \mathrm{~g}$ mixed flour and $50 \mathrm{~g}$ banana bract flour was the least accepted among the tasters, receiving the lowest averages for the "aroma, texture, taste and overall impression" attributes. A significant difference $(\mathrm{P} \leq 0.05)$ was observed among the 
P1 samples elaborated with the lowest banana bract flourconcentration, were the most accepted.

According to Lambert et al. (2006), the main cookie quality attributes are appearance, taste and texture. All cookieformulations were well-accepted by the tasters, with hedonic averages ranging from 6.69 ("liked slightly") to 7.78 ("liked moderately"). C3 formulation with the highest banana bract flour content was the highest ranked, except for the "color" attribute that showed no statistical difference among the formulations.

The cookies producedhad higher averages than those obtained by Queiroz et al. (2017) who developed gluten-free cookies with potato starch and coconut flour, with averages ranging from 6.0 ("like") to 7.0 ("like") for sensory attributes. The study by Giovanella et al. (2013), who developed gluten-free cookies added with quinoa flour and potato starch, obtained similar results in terms of taste, texture and overall impression.

\section{Conclusions}

In this study, further discussions were sought on the production of new, affordable, and easily accessible gluten-free products. The banana bract flour (Musa ssp.) analysisrevealed its considerable nutritional value and may be considered a significant nutritional supplement based on the dietary fiber content.

This study showed the feasibility of using a little known flour such as banana bract flour, as a wheat flour replacementon gluten-free foods production. It was seen that both pizza and cookie doughsadded with bract flour had a good response from tasters, with an overall acceptance above $65 \%$, showing that it staste would not be a problem for products elaboration. It has shownitspotential as a raw material for new products, soit further testsshould be performed for it to enter the market in the future.

The gluten-free pizza and cookie doughs development added with banana bract flour has allowed obtaining more nutritious products with higher fiber and phenolic compounds and lower carbohydrate content. Sensory analysis showed that the formulations were accepted, with the best evaluation for cookie samples.

\section{References}

AOAC. Association of Official Analytical Chemists (1995). Official methods of analysis of the Association of the Analytical Chemists.16 ${ }^{\text {th }}$ EditionGaithersburg, M.D, USA.

AOAC. Association of Official Analytical Chemists (2000). Official methods of analysis of the Association of the Analytical Chemists. $17^{\text {th }}$ Edition. Gaithersburg, M.D, USA.

AOAC. Association of Official Analytical Chemists (2005). Official methods of analysis of the Association of the Analytical Chemists. $18^{\text {th }}$ Edition. Gaithersburg, M.D, USA.

AOAC. Association of Official Analytical Chemists (2011). Official methods of analysis of the Association of the Analytical Chemists. $18^{\text {th }}$ Edition. Gaithersburg, M.D, USA.

Aprodu, I., \& Banu, I. (2015). Influence of dietary fiber, water, and glucose oxidase on rheological and baking properties of maize based gluten-free bread. Food Science and Biotechnology, 24(4), 1301-1307.

Asami, D.K., Hong, Y.J., Barrett, D.M., \& Mitchell, A.E. (2003). Comparison of the Total Phenolic and Ascorbic Acid Content of Freeze-Dried and Air-Dried Marionberry, Strawberry, and Corn Grown Using Conventional, Organic, and Sustainable Agricultural Practices. Journal of Agricultural and Food Chemistry, 51, 1237-1241.

Aquino, C.F., Salomão, L.C.C., Siqueira, D.L., Cecon, P.R., Ribeiro, S.M.R. (2014). Teores de minerais em polpas e cascas de frutos de cultivares de bananeira. Revista Agropecuária Brasileira, 49.

Basumatary, S., \& Nath, N. (2018).Assessment of Chemical Compositions and in vitro Antioxidant Propertiesof Musa balbisiana 
Colla Inflorescence. International Journal of Pharmaceutical Research, 10 (1).

Bhaskar, J.J., Chilkunda, N.D.\& Salimath, P.V. (2012). Banana (Musa sp. var. elakki bale) flower and pseudostem: dietary fiber and associated antioxidant capacity. $J$. Agricultural FoodChemistry, 60, 427-432.

Bingham, A., Boucher, C., Boyce, J. (2011). Textural Variations of Pizza in Commercial Establishments. Project Report, Faculty of Worcester Polytechnic Institute. Journalof Texture Studies34.

Bligh, E.G., \& Dyer, W.J. (1959). A rapid method of total lipid extraction and purification. Canadian Journal of Biochemistry and Physiology, 37 (8) 911917.

Brasil. Ministério da Agricultura, Pecuária e o Abastecimento (2005). Resolução $\mathrm{n}^{\circ}$ 263, de 22 de setembro de 2005. Aprova o regulamento técnico para produtos de cereais, amidos, farinhas e farelos. Diário Oficial da União, Poder Executivo, DF, Brasília.

Brasil. Ministério da Saúde (2001). Agência Nacional de Vigilância Sanitária. Resolução RDC $n^{\circ} 40$, de 21 de março de 2001. Dispões sobre o Regulamento Técnico sobre Rotulagem Nutricional Obrigatória de Alimentos e Bebidas embalados. DOU. Diário Oficial da União, Poder Executivo, DF, Brasília.

Brasil. Ministério da Saúde (2012). Agência Nacional de Vigilância Sanitária. Resolução RDC n ${ }^{\circ}$ 54, de 12 de novembro de 2012. Dispões sobre o Regulamento Técnico sobre Informação Nutricional Complementar. DOU. Diário Oficial da União, Poder Executivo, DF, Brasília.

Borges, C.D.\& Mendonça, C.R.B. (2019). Processamento de Frutas e Hortaliças. Appris Editora. $1^{\text {a }}$ Edição, ISBN: 978-85537-0056-1, 228p.

Borges, A.M., Pereira, J., \& Lucena, E.M.P. (2009). Caracterização da farinha de banana verde. Ciência e Tecnologia de Alimentos. Campinas, 29(2), 333-339.
Cecchi, H.M. (2003). Fundamentos teóricos e práticos em análise de alimentos. 2.ed. Campinas: Editora UNICAMP, 207p.

Cristo, T.W., Santos, M.M.R., Candido, C.J., Santos, E.F., \& Novello, D (2018). Cupcake com adição de farinha de casca de melancia (Citrulluslanatus): caracterização físico-química e sensorial. Ambiência Guarapuava (PR), 14 (2), 331-342.

Dutcoski, SD. Análise sensorial de alimentos (2013). $4^{a}$ Edição. Curitiba: Champagnat Pucpress, 531p.

El Khoury, D., Balfour-Ducharme, S., \&Joye, I. J. (2018). A Review on the Gluten-Free Diet: Technological and Nutritional Challenges. Nutrients, $10 \quad$ (10), 1410. doi:10.3390/nu10101410

El-Beltagi, H.S., El-Senousi, N.A., Ali, Z.A., Omran, A.A. (2017). The impact of using chickpea flour and dried carp fish powder on pizza quality. PlosOne. 12 (9), 1-15.

Farage, P., PuppinZandonadi, R., Cortez Ginani, V., Gandolfi, L., Yoshio Nakano, E., \&Pratesi, R. (2018). Gluten-Free Diet: From Development to Assessment of a Check-List Designed for the Prevention of Gluten Cross-Contamination in Food Services. Nutrients, 10(9), 1274.

Fawole, O.A., Makunga, N.P., \&Opara, U.L. (2012). Antibacterial, antioxidant and tyrosinase-inhibition activities of pomegranate fruit peel methanolic extract. $B M C$ Complementary and Alternative Medicine 12, 200-218.

Fingolo, C.E., Braga, J.M., Vieira, A.C., Moura, M.R., \& Kaplan, M.A. (2012). The natural impact of banana inflorescences (Musa acuminata) on human nutrition. Anais da Academia Brasileira de Ciencias, 84 (4), 891-898.

Farias, Adenilma da Silvia. Gluten-restricted pizza doughs. Monograph (Specialization) Center of Excellence in Tourism, University of Brasília, Brasília, 2009.

Freitas, C.J., Valente, D.R.E., Cruz, S.P. (2014). Caracterização física, química e sensorial de biscoitos confeccionados com farinha de semente de abóbora (FSA) e 
farinha de semente de baru (FSB) para celíacos. Demetra: alimentação, nutrição e saúde, Rio de Janeiro, 9 (4), 1003-1018.

Fritz, R.D. \& Chen, Y. (2017). Kernel-based gluten contamination of gluten-free oatmeal complicates gluten assessment as it causes binary-like test outcomes. International Journal of Food Science \& Technology, 52, 359-365.

Fry, L., Madden, A.M., Fallaize, R. (2018). An investigation into the nutritional composition and cost of gluten-free versus regular food products in the UK. Journal of Human Nutrition and Dietetics., 31(1), 108120.

Gao, Y., Janes, M.E., Chaiya, B., Brennan, M.A., Brennan, C.S., \& Prinyawiwatkul, W. (2018). Gluten-free bakery and pasta products: prevalence and quality improvement. International Journal of Food Science \& Technology, 53, 19-32.

Gawlik-Dziki, U. (2012). Changes in the antioxidant activities of vegetables as a consequence of interactions between active compounds. Journal of Functional Foods, 4 (4), 872-882.

Giovanella, C., Schlabitz, C., Souza, C.F.V. (2013). Caracterização e aceitabilidade de biscoitos preparados com farinha sem glúten. Revista Brasileira de Tecnologia Agroindustrial. Paraná, 7(1), 965-976.

Gonnet. J.F. (1998). Colour effects of copigmen-tion of anthocyanins revisited-1. A colorimetric definition using the CIElab scale. Food Chemistry. 63 (3), 409-415.

Grooms, K.M., Ommerborn, M.J., Pham, D.Q., Djoussé, L., \&Clark, C.R. (2013). Dietary fiber intake and cardio metabolic risks among US Adults, NHANES 1999-2010. The American Journal of Medicine, 126(12), 1059-67.

Guimarães, M.M., Silva, M.S. (2009). Qualidade nutricional e aceitabilidade de barras de cereais adicionadas de frutos de murici-passa. Revista Instituto Adolfo Lutz, 68(3), 426-433.

IBGE, Instituto Brasileiro de Geografia e Estatística. Pesquisa de orçamentos familiares. Tabelas de composição nutricional dos alimentos consumidos no Brasil. Rio de Janeiro, p.1-351, 2011.

Labuza, T.P. (1975). Water relations of foods. New York: Academic Press, 155-172.

Lambert, E.A., Pereira, J.G., Lavinas, T.S., Silva, L.J., Passianoto, M., Gregorio, S.R. (2006). Avaliação descritiva quantitativa de biscoito salgado. Revista Universidade Rural: Série Ciências Exatas e da Terra, 25(1), 9-14.

Mariani, M, Oliveira, V.R., Faccin, R., Rios, AO, Venzke, J.G. (2015). Elaboração e avaliação de biscoitos sem glúten a partir de farelo de arroz e farinhas de arroz e soja. Brazilian Journal of Food Technology, 18(1), 70-78.

Medeiros, M.J., Oliveira, P.A.A.C., Souza, J.M.L., Silva, R.F., Souza, M.L. (2010). Composição química de misturas de farinhas de banana verde com castanha-dobrasil. Revista Instituto Adolfo Lutz. São Paulo, 69(3), 396-402.

Monteiro, S.Z. (2013). Utilização de mesclas de farinha de arroz, inhame e quinoa na elaboração de disco de pizza pré assado sem glúten e sem lactose. Trabalho de Conclusão de Curso- Instituto de Ciência e Tecnologia de Alimentos, Universidade Federal do Rio Grande do Sul, Porto Alegre.

Padalino, L., Conte, A., \& Del, Nobile, M.A. (2016). Overview on the general approaches to improve gluten-free pasta and bread. Foods, 5, 87.

Padam, B.S., Tin, H.S., Chye, F.Y., \& Abdullah M.I. (2012). Antibacterial and antioxidative activities of the various solvent extract of banana (Musa paradisiaca cv. Mysore) inflorescences. Journal of Biological Sciences, 12 (2) 63-73.

Pratesi, Riccardo.; GANDOLFI, Lenora. Celiac disease: the disease with multiple faces. Journal of Pediatrics.v. 81, n.5, p. 2005.

Queiroz, A.M., Rocha, R.F.J., Da, Garruti, D, dos S, Silva, A., De P.V., Da; Araujo, I.M.S. (2017). Elaboração e caracterização de cookies sem glúten enriquecidos com 
farinha de coco: uma alternativa para celíacos. Brazilian Journal of Food Technology, 20.

Russo, C.B., Sostisso, C.F., Pasqual, I.N., Novello, D., Dalla Santa, H.S., Batista, M.G. (2012). Sensory acceptability of the whole wheat and flaxseed (Linum usitatissimum L.) flours-added pizza dough among adolescent customers. Revista Instituto Adolfo Lutz, 71(3), 488-94.

Sciarini, L.S., Ribotta, P.D., León, A.E., Pérez, G.T. (2010). Effect of Hydrocolloids on Gluten-Free Batter Properties and Bread Quality. International Journal of Food Science and Technology 45, 2306-12.

Scorsatto, M., Pimentel, A.C., Silva, A.J.R., Sabally, K., Rosa, G., \&Oliveira, G.M.M. (2017). Avaliação de Compostos Bioativos, Composição Físico-Química e Atividade Antioxidante In Vitro da Farinha de Berinjela. Internacional Journal of Cardiovascular Sciences, 30(3), 235-242.

Shah, M.P., Reddy, G.V., Banerjee, R., Babu, P.R., \&Kothari, I.L. (2005). Microbial degradation of banana waste under solid state bioprocessing using two lignocellulolytic fungi (Phylosticta spp. MPS-001 and Aspergillus spp. MPS-002) Process Biochemistry, 40, 445-451.

Sheng, Z.W., Ma, W.H., Gao, J.H., Yang, Bi, Zhang, W.M., Dou, H.T., Jin, Z.O. (2011). Antioxidant properties of banana flower of two cultivars in China using 2,2-diphenyl1-picrylhydrazyl (DPPH,) reducing power, 2,2'-azinobis-(3-ethylbenzthiazoline-6sulphonate (ABTS) and inhibition of lipid peroxidation assays. African Journal of Biotechnology, 10(21), 4470-4477.

Sheng, Z.W., Ma, W.H., Jin, Z.Q., Bi, Y., Sun, Z.G., Dou, H.T., Gao, J.H., Li, J.Y., \& Han, L.N. (2010). Investigation of dietary fiber, protein, vitamin $\mathrm{E}$ and other nutritional compounds of banana flower of two cultivars grown in China, African of Journal Biotechnology, 9(25), 3888-3895.

Silvia, M.R., Silvia, M.A.A.P., Chang, Y.K. (1998). Utilização da farinha de jatobá (Hymenaea stigonocarpa Mart.) na elaboração de biscoitos tipo cookie e avaliação de aceitação por testes sensórias afetivos uni variados e multivariados. Ciência e Tecnologia de Alimentos [online], 18(1), 25-34.

Sivakumar, P. S., Panda, S. H., Ray, R. C., Naskar, S. K. \& Bharathi, L. K. (2010). Consumer Acceptance Of Lactic AcidFermented Sweet Potato Pickle. Journal of Sensory Studies, 25, 706-719.

Statsoft, I.N.C. (2004). Statistica for Windows: computer program manual. Tuls a, OK, USA.

Taco (2011). Tabela brasileira de composição de alimentos / NEPA - UNICAMP.$4^{\circ}$ Edição Revisada e Ampliada, -Campinas: NEPA- UNICAMP, 161.

Takatsui, F. (2001). Sistema CIE LAB: análise computacional de fotografias. Tese (Mestrado em Ciências Odontológicas). Universidade Estadual Paulista, São Paulo.

Verma, A.K., Gatti, S., Galeazzi, T., Monachesi, C., Padella, L., Baldo, G.D., Catassi, C., (2017). Gluten Contamination in Naturally or Labeled Gluten-Free Products Marketed in Italy. Nutrients, 9(2), 115.

Vialta, A. (2010). Brasil FoodTrends 2020. São Paulo, Disponível em: $<$ http://www.brasilfoodtrends.com.br/Brasil Food_Trends /index.html $>$.

Xu, L. G..; Shen, W.X. (1988). Study on the PTFE closed-vessel microwave digestion method in food elemental analysis. Fresenius Zeitschrift AnalytischeChemie, $332,45-47$.

\section{Acknowledgment}

The current manuscript was carried out with the UEMS support, Institutional scientific initiation program - PIC/UEMS.The authors would like to thank the Higher Education Personnel Improvement Coordination (CAPES) and the National Council for Technological and Scientific Development (CNPq) for the scholarships granted at the Masters and Scientific Initiation levels. We also confirm that the authors have no conflict of interest. 